\title{
The Politics of Formal Schooling in Refugee Contexts: Education, Class, and Decision Making among Congolese in Uganda
}

\author{
Christina Clark-Kazak
}

\begin{abstract}
Based on ethnographic research with over four hundred Congolese refugees in Kampala and Kyaka II refugee settlement, Uganda, this article interrogates the politics of education-both historically in the Democratic Republic of Congo and currently in migration contexts in Uganda. Formal education was an aspiration for all young people in the study, irrespective of current educational level. Moreover, it is a priority for the United Nations High Commissioner for Refugees (UNHCR) and many other organizations working with refugees. Drawing on the experiences and views of Congolese young people, this article analyzes the socio-political importance they accord to formal schooling. It then analyzes the degree to which these political aspects of education are manifested in daily decision-making processes in families, households, communities, and high-level politics. The author concludes with some reflections on how researchers and practitioners working in migration contexts can recognize and take into account the politicized nature of education.
\end{abstract}

\section{Résumé}

Se basant sur des recherches ethnographiques réalisées auprès de plus de quatre cents réfugiés congolais dans les camps de Kampala et de Kyaka II, en Ouganda, cet article s'interroge sur la politique de l'éducation, à la fois d'un point de vue historique, dans la République populaire du Congo, et d'un point de vue contemporain, dans le contexte de la migration en Ouganda. Tous les jeunes gens interrogés dans le cadre de la recherche aspiraient à faire des études scolaires, peu importe leur niveau de scolarisation actuel. En outre, l'enseignement est une priorité du Haut Commissariat des Nations Unies pour les réfugiés (UNHCR) et de nombreuses autres organisations travaillant avec des réfugiés. S'appuyant sur les expériences et les opinions des jeunes du Congo, cet article analyse l'importance sociopolitique que ces derniers accordent aux études scolaires. Il cherche ensuite à définir dans quelle mesure les aspects politiques de l'éducation se manifestent dans les procédures de prise de décisions quotidiennes des familles, des ménages, des communautés et des hautes sphères politiques. L'article se termine par des réflexions sur la façon dont les chercheurs et les praticiens travaillant dans des contextes de migration peuvent reconnaitre et tenir compte de la nature politisée de l'éducation.

\section{Introduction}

As part of a larger research project focussing on the political narratives and experiences of Congolese young people living as refugees in Uganda, ${ }^{1}$ over four hundred research subjects were asked about their aspirations for the future. All respondents, despite varying levels of formal education from none to university level, cited further studies as one of their goals. Similarly, development and refugee agencies prioritize formal schooling, citing it is a solution to many problems, from high birth rates to infant mortality. ${ }^{2}$ Education specialists are better placed to evaluate these claims and the technical merits of different types of formal schooling in refugee settings. ${ }^{3}$ Instead, in this article, I explore the political reasons for this convergence of opinion about the importance of education. In particular, I interrogate the ways in which formal education is implicitly and explicitly linked to class and power relations-both historically in the Democratic Republic of Congo (DRC), as well as in contemporary situations of displacement for Congolese refugees in Kampala and Kyaka II refugee settlement in Uganda. Through an analysis of decision making at household, community, and policy levels, the article also highlights the ways in which power relations create opportunities and 
barriers to realizing the anticipated political benefits of formal schooling.

Research findings reveal that formal education impacts power relations within families and households, particularly amongst peers. Similarly, schooling facilitates young people's access to, and visibility in, formal community decision-making structures. In high-level politics, such as access to political office, however, the benefits of formal education for refugees are less clear-cut. While education intersects with class and provides some political visibility, it does not necessarily lead directly to the tangible economic and political benefits for which many young Congolese in refugee contexts hope. This analysis of the politics of education at family, household, community, and policy levels demonstrates the importance of recognizing and taking into account the politicized nature of formal schooling when working with refugees. The article concludes with some implications for research and practice.

\section{Research Context, Methodology, and Conceptual Framework}

Research presented in this article was carried out with Congolese refugees in Kampala and Kyaka II refugee settlement from September 2004 to December 2005. Uganda's capital city, Kampala is a large urban centre that has attracted migrants from across the country, as well as neighbouring states in the Great Lakes region. However, according to the settlement policy in Uganda at the time of research, ${ }^{4}$ refugees are not officially supposed to live in the city and thus do not receive humanitarian assistance or have access to social services. In contrast, Kyaka II is a designated refugee settlement in an isolated, rural area of western Uganda. Refugees arriving in the settlement are registered, documented, and allocated a plot of land, where they are supposed to engage in subsistence farming under the United Nations High Commissioner for Refugees (UNHCR)/Government of Uganda self-reliance strategy.

I collected data using a variety of qualitative methods, including semi-structured interviews, focus group discussions, writing exercises, and observation. Over four hundred research subjects were identified using snowball and purposive sampling. Snowball sampling can result in bias towards respondents who share certain characteristics and/ or are more visible, thereby undermining representivity. ${ }^{5}$ Purposive sampling was thus also used to identify research subjects through multiple entry points. Despite time and logistical constraints, the study sought to include young people of different ethnicity, sex, and age, living in different circumstances. I carried out research, without interpretation, in French, English, and basic Swahili. However, due to my limited Swahili language skills, the research over-represents people who could speak some French or English and hence had completed some formal education. There is a consequent bias towards middle-class research subjects. I have translated all direct quotations in French or Swahili into English.

Data included in the article were collected as part of a larger study exploring the political engagement of young Congolese refugees in Uganda. The research took as its point of departure an approach to young people as political actors and interrogated the ways in which young people engaged in decision making at family, household, community, and policy levels. In this way, the study was not specifically focused on education. Rather, education-particularly higher education-emerged as a theme in discussions with young refugees about their plans and hopes for the future. When probed about the reasons why they aspired to higher education, many cited a belief that formal schooling would bring them status and hence greater access to decision making. This paper explores these political meanings ascribed to formal education and the degree to which they are realized for young people in the study.

My political analysis takes into account both formal high-level political processes and the politics of everyday life. Such an approach "challenges the conventional view of politics as limited to formal processes of governments and market relationships in the public sphere." ${ }^{6}$ Both refugees and young people are noticeably absent, and usually legally excluded, from these high-level institutions and the formal economy. In Uganda, for example, refugees are legally prohibited from participating in political activities, while in the DRC, people under the age of eighteen are legally disenfranchised. However, Congolese young people are integral-although not necessarily equal-members of households, families, and communities in Kyaka II and Kampala. Building on the feminist notion that the personal is political, this article broadly conceptualizes "politics" to include decision-making processes from family to policy levels: "The political cannot be restricted to a certain type of institution, or envisaged as constituting a specific sphere or level of society. It must be conceived as a dimension that is inherent in every human society and that determines our very ontological condition."7 Such an approach allows an interrogation of the ways in which access to, and experiences of, formal education are inherently politicized-that is, bound up within power relations and linked to decisionmaking processes and structures.

In this article, "young people" refers to all individuals who have passed puberty, but who have not yet married. This is a social definition that emerged from the majority of my research subjects' experiences and views on childhood, youth, adulthood, and old age in their changing social 
contexts. Such a perspective differs from many prevailing chronological definitions of children and young people that are codified in international law, particularly the United Nations Convention on the Rights of the Child and the African Convention on the Rights and Welfare of the Child. It is these legal chronological definitions that are the basis of programmatic interventions by many organizations working on the ground. However, many scholars have argued that childhood is socially constructed in particular times and places. ${ }^{8}$ In this paper, "social age" is thus distinguished from biological development in a way similar to gender and sex. ${ }^{9}$ A social age analysis takes into account the socially constructed roles ascribed to children and young people, as well as power dynamics in inter- and intragenerational relationships. In this paper, particular attention will be paid to these micro-level politics in relation to formal education and access to decision making in families and households.

The term "refugee" is used to describe the circumstances of people who have come to Uganda in the context of generalized conflict and insecurity in the DRC. It therefore applies not only to those who have been legally recognized as refugees by the Government of Uganda and/or the UNHCR, but also to those who self-identify as refugees but have not formally registered as such with UN and government officials. In keeping with many of my informants' selfdefinition, I prefer to use the term "Congolese" rather than "refugee" to describe them.

Finally, in this paper, education is used narrowly to refer only to formal, classroom education. While it is recognized that young refugees may also experience other forms of education, including mentoring and apprenticeship, in keeping with the theme of this special issue, I will focus solely on formal schooling here.

\section{Illustrative Case Study: Marie's Experiences}

I will now highlight the experiences of one young Congolese woman, "Marie,"10 as an illustrative case. The following is an excerpt from a much longer narrative, which was constructed over several interviews and meetings with Marie during ethnographic research over a fifteen-month period. ${ }^{11}$ Marie's situation is not intended to be representative of all four hundred Congolese young people in the study. Indeed, her experiences are exceptional because she is one of very few refugees to win a scholarship to study at university. Rather, her story illustrates some broader themes about the politics of education that will be compared and contrasted with the experiences of young people from the larger dataset, some of whom I cite in the analysis below.

Marie is from Bukavu, South Kivu, in eastern DRC. While fleeing armed conflict in 1996 (when Marie was in her early teens), she was separated from her family. Upon arrival in Uganda, Marie went to Kyangwali refugee settlement to look for her family. She met another Congolese family, with whom she stayed until 1998. Marie initially supported herself by selling cloth until she won a scholarship from the Hugh Pilkington Charitable Trust (now the Windle Trust) to study social work and social administration at university. While she was on scholarship, "they paid for everything."

After completing her bachelor's degree in late 2003, Marie looked for employment. Despite her university qualification in an applied field and knowledge of English, French, Swahili, and Luganda, she was unable to find work. So, she volunteered at a refugee organization as a translator. She also did some counselling there, and felt like she was able to practically use her social work degree. Marie received a small stipend of 5,000 $\mathrm{USH}^{12}$ for each day she volunteered and thus earned enough to pay basic expenses, including 30,000 USH room rent. However, in May 2004, the refugee organization, citing confidentiality reasons, decided that it would no longer use refugees as translators. Marie then tried to make ends meet by giving English and French lessons for 10,000 USH per student per month. She also continued to look for work at other refugee and development organizations, but has been unsuccessful. Marie believed that she was being discriminated against because of her nationality. With the high level of unemployment in Uganda, Marie assumed that the Ugandan government put pressure on organizations to hire Ugandans.

In 2000, she discovered that her sixteen-year-old sister and thirteen-year-old nephew were living in an orphanage in Bukavu, run by a Catholic priest. Marie did not know where the rest of her family was and has lost hope of ever finding them. In July 2004, her sister and nephew came to live with her in Kampala after fleeing renewed fighting in Bukavu, during which her sister was raped.

Marie was actively involved in an association for refugee youth in Kampala and had strong opinions about UNHCR policy and issues facing Congolese young people. She argued that UNHCR should do more to help Congolese young people to study, "since you need education for a better future."

By January 2005, Marie was finding it increasingly difficult to make ends meet in Kampala through odd teaching jobs. UNHCR had rejected her application for resettlement, saying that she had "durable solutions" in Uganda because of her education and knowledge of languages. However, Marie felt that they did not understand her challenges in finding work and integrating into Ugandan society.

In August 2005, Marie's cousin and sister returned to the DRC because it was too difficult for her to support them without a stable income. In October 2005, her brother, 
who had been living in South Africa, died. Marie collected money from friends and family in order to buy a plane ticket to South Africa, so she could attend the funeral. By the end of my fieldwork in December 2005, she had not returned to Kampala.

Despite the uniqueness of Marie's case, it illustrates several themes about the politics of education, which are reflected in the broader dataset. First, as mentioned in the introduction, every young person in my study, despite their very different backgrounds, cited education as a hope for the future. Indeed, even though Marie had not yet tangibly benefited from her university degree in terms of stable employment, she insisted that UNHCR should provide young people with more educational opportunities "since you need education for a better future." This belief in a "better future" through education echoes many other young people's views. For example, David, a young Congolese male in Kampala, said, "I know that a good future depends on education. If I have a good education, the future will be OK." According to eighteen-year-old Gaston in Kyaka II, because he has never studied, he thinks that he will have "a bad future.” Beaumont, living with his family in Kyaka II, reported that he could only consider the future after completing school: "If I had the means, I could study. After my studies, I could make plans." This convergence of opinion is interesting: why do research subjects consider education to be so important for their future goals?

The following sections demonstrate how young people aspire to and/or use formal schooling as a means to greater decision making at household, community, and policy levels. This political analysis highlights the transformative potential of education, but also the ways in which formal schooling may entrench power relations, particularly through class and differential access. In this way, formal education only partially fulfills the aspirations that Marie and the other young people in the study attribute to it, especially in terms of high-level politics.

\section{High-Level Politics, Class, and Power}

Before analyzing the relationship between formal education and high-level decision making in refugee contexts in Uganda, it is important to foreground this discussion within the historical context in the DRC. There, since colonization, education has been a means to social status, wealth, and political power. Under Belgian rule, Congolese with formal western education qualified for white-collar employment and occupied a special status as évolués (literally translated as "evolved people"), which they passed on to their children. ${ }^{13}$ At independence, évolués consolidated their position as members of the upper middle class and political elite. ${ }^{14}$
Formal education thus partially determines social class in the DRC, with important political implications.

Similarly, many Congolese living in Uganda identified the intersection of education and socio-political status, as shown in my analysis of data from writing exercises collected from 148 (107 male and 41 female $)^{15}$ students in secondary school and upper-level primary school in Kyaka II refugee settlement. These written statements reveal a widespread belief among students that education will enable them to become "big people" (including: teacher, headmaster, doctor, nurse, bank manager, lawyer, engineer, NGO driver, pilot, tax collector, police official, minister, Member of Parliament, president) with "important" decision-making roles. For example, one male student wrote, "In the future, I want to be a doctor treating people because someone who has education has the right to speak in the community." Similarly, another young male argued, "If you are talking in public, they will listen to you." On several occasions, Peter, a youth leader in Kyaka II, described the perceived link between education and leadership and decision-making opportunities. When asked about his future aspirations, he said, "My plans are very big. I don't know if they will come. I want to study. Then I can be a leader and do my best to explain the problems facing refugees in public ... in the UN." In a later discussion about the political situation of people from the Hema ethnic group in the DRC, Peter returned to the topic of formal schooling: "I need education to protect myself when I go back. We the Hema are cattle keepers and they say we're not supposed to study. No one can see us as educated, as a president, a doctor, a minister. But, if we come back educated, they will see that Hema can also be politicians, so will harass Hema less."

Peter's belief in education as a way to political leadership is echoed by many others in my study. Some young people, such as eighteen-year-old Francis, who lives with peers in Kyaka II, believe that educated leaders will bring peace and development to the DRC: "You can bring development when you finish your education." Similarly, Eric and Etienne, selfdescribed "intellectuals" and members of a refugee association in Kyaka II, would like to study at university and return to the DRC to "help the common people" and "to contribute to the reconstruction of my country," respectively. Philippe, a male adult in Kyaka II, declared that his "only wish" was for his children to study "so that they can become people to lead our country. Otherwise, how can one lead? [...] We need a man who is well cultured and wise." Philippe's use of the word "man," and the fact that all other examples (except Marie) cited above come from males, is reflective of differential gender implications of education, as will be discussed in the final section below. 
While the expected benefits of formal schooling in terms of political leadership and access to high-level decision making are clear, the tangible value of education for Congolese young people living in refugee contexts in Uganda is ambiguous, as illustrated in Marie's case. Despite her university education, she is unable to find full-time employment. The assumed causal connection between formal schooling and higher-paying, white-collar jobs is thus not necessarily reflected in the experiences of young people in this study. In contexts of widespread poverty and unemployment, such professional positions may be scarce, and priority could be given to citizens of the host country, as in Marie's case. Moreover, formal education does not necessarily prepare graduates for the working class jobs that are available. Schooling removes young people from the labour force for the duration of their studies, during which they may not benefit from practical apprenticeships and onthe-job experience that they otherwise would have gained. ${ }^{16}$ More importantly, the status attached to formal education and the societal expectations of white-collar work make graduates reluctant to take on jobs that are available and potentially lucrative, but are perceived to be "below them." For example, Marie made good money selling cloth before she started university. However, now that she has a degree, she would not consider any kind of petty trading, believing that the only jobs worthy of her education are in NGOs, multilateral agencies, or teaching.

Indeed, those refugees from urban, educated backgrounds who found themselves living beside uneducated Congolese in Kampala's slums and Kyaka II refugee settlement often self-identified as "intellectuals" to distinguish themselves from others whom they regarded as "peasants" or "villagers." Philippe, the adult head of family cited above, described his life in Kyaka II: "It is not good here because we Congolese, we are used to having money and living a bourgeois life. Now we are like villagers. We have moved 12,000 kilometres backwards. I'm an intellectual, but I find myself here like a small ant." In an informal discussion with self-identified young évolués, one lamented, "After six months in this bush, I will no longer be an intellectual." This differentiation amongst refugees demonstrates the continued relevance of class in refugee contexts, even when people from different backgrounds live in similar situations. In this way, education continues to be an important marker of status in refugee communities. For example, teachers at Bujubuli Secondary School are highly respected in Kyaka II, referred to simply as "teacher" as a term of respect. They are also given credit at shops and bars. Secondary students also take pride in the visible marker of education that their school uniforms bring, even though uniforms increase the cost of their schooling, making it unattainable for many.

In contrast, those young people who were previously educated in the DRC, but who can not afford to attend school in Uganda, keenly feel this loss of status and direction. For example, Véronique, a young women living with her family in Kampala, explains why she does not have any Ugandan friends: "I just stay at home. Ugandans go to school, so there is no way to meet them. If you don't go to school, they look at you as a ragamuffin. They see you as worthless. For me, I just cry because I want to go to school." I observed the social impact of education on Olivier, a young male who came from a prominent, wealthy family in eastern DRC. When he first arrived in Kyaka II, his mother could not afford school fees. Olivier was despondent and dismissive of the low quality of education in the settlement. However, once he started attending school in February 2005, his spirits improved dramatically. He made many friends, including Peter (cited above), with whom he discussed homework and set tests.

\section{Community Politics and Access to Policy Makers}

Social status and class are linked to another level of analysis in this study: decision making in formal community structures. Here, the link between education and political access is clear. Like Marie in the refugee youth association in Kampala, the majority of young people in leadership positions in refugee organizations and structures have at least secondary education. At the time of research, the executive committees of two such associations analyzed for this study were composed only of young people with secondary or university education. Moreover, the designated "youth" representative on the Refugee Welfare Committee, a formal representative structure in Kyaka II, was enrolled in secondary school, where he also occupied a student leadership position.

Education also increases political opportunities at a policy level because UNHCR, the Ugandan government, and many NGOs use schools as sites in which to "mobilize" young people, either to engage in "sensitization activities" or to undertake "consultations" regarding policy or programming. ${ }^{17}$ Researchers also often use schools as convenient sites for accessing children and young people. Moreover, extracurricular activities for young people are usually based at schools, making them more accessible to those enrolled in formal education. As a result, young people in formal schooling have greater access to decision making and programming than their counterparts who do not attend school.

The ability to speak a western language is another concrete political asset of formal education. Instruction in schools is 
in French in the DRC and English in Uganda. This knowledge of French or English, coupled with exposure to "sensitization" activities (described above), allows young people with formal education to speak the same language-literally and figuratively-as policy makers from NGOs, UNHCR and governments. ${ }^{18}$ In public debates on high-level political issues, French and English are also used as the lingua franca in the absence of a common national vernacular language in the DRC and Uganda, respectively. Even in the context of the study upon which this article is based, when research subjects discussed high-level political issues, including leadership, elections, and citizenship, I observed a change in their grammar and vocabulary. They used formal French in these circumstances, sometimes switching from English, even when this excluded non-francophone peers. Research subjects are more eager to learn English than Luganda in Kampala and Lutoro in Kyaka II. For example, Bondeko, a young male who lives with his younger sister in Kampala takes English lessons at Jesuit Refugee Services, but is not interested in learning Luganda: "At least English is an international language." This analysis shows that formal schooling increased young people's access to formal decision-making structures in communities, as well as made them more visible to policy makers.

\section{Education and Social Age: Micro-politics in Families and Communities}

At the third level of analysis, formal schooling is important in the micro-politics of everyday interactions in families and communities. First, knowledge is an attribute of social age $^{19}$ in many Congolese groups. Historically, knowledge has been equated with the wisdom of experience. Research subjects, particularly adults, attributed certain levels of knowledge or intellectual development to different stages in the life cycle. They believed that children are by definition ignorant, young people have more knowledge, and adults, particularly elders, are inherently wise. For example, Murhabazi, an older Congolese leader in Kyaka II, defined a child as "someone who is not yet conscious of what he's doing, who can't form plans." Similarly, another male elder considered a child as "someone who doesn't reason" and a young person as "someone who doesn't understand." However, formal education is an increasingly important influence on access to decision making within families and communities, especially in contexts of migration and urbanization. While full-time education or a hiatus in studies results in prolongation of childhood or youth, education is seen as an investment that will eventually yield higher socio-political status.

Moreover, there is some evidence to suggest that formal schooling has the potential to transform intergenerational power relations, especially in migration contexts where students learn the language of the host country in school. In the present study, young people with more formal schooling than one or both parents often represent their family in interactions with refugee and Ugandan officials that require knowledge of a western language. Research undertaken in other contexts also shows how the fact that children become spokespeople for their families increases their access to decision-making processes. ${ }^{20}$

Education is also important for intragenerational relationships, as demonstrated in my analysis of decision making within households composed of peers. In forced migration contexts, such peer networks may be more prevalent than in home countries prior to migration due to family separation and changing social norms with respect to unmarried young people moving out of family networks. ${ }^{21}$ In my long-term observation of various peer households in both Kampala and Kyaka II, I noted that formal schooling factored into young people's access to decision making. This is demonstrated in Marie's case, for example, by her interactions with her sister and cousin, who both dropped out of secondary school at an early age. I had little opportunity to interact with Marie's younger relatives, even when I made explicit attempts to do so. On one visit to Marie's home to interview her younger sister, for example, I instead encountered an informal discussion amongst Marie and some of her educated friends. The younger relatives were not engaged in the conversation and at one point Marie asked her sister and nephew to go and prepare tea, effectively removing them from the research site.

Similarly, in a peer household in Kyaka II composed of young people who were from the same ethnic group but were not related to one another, fifteen-year-old Dominic was the only male to attend primary school. All others were studying, or had studied, at secondary school. Although of similar chronological age to his peers, Dominic was considered to be socially younger than other males in the household and had consequently less access to decision making about collective resources and division of labour. For example, when other males were present, Dominic rarely spoke. Indeed, when asked about decision making in the household, he named Benjamin-the eldest male, who had also completed secondary school-as the person responsible. Similarly, Catherine, the eldest female in the group, described Dominic's labour as "children's work."

In analyzing the micro-politics of education in families and households, it is also important to recognize gender relations. Indeed, young men and women in this study experience and view education differently. The former believe education will open up decision-making opportunities in community and policy spaces; the latter see 
education primarily in terms of negotiating power relations and decision making within families and households. This highlights the intersection of multiple subject positions, including gender, class, and social age, in determining the political salience of education.

\section{The Politics of Education: Implications for Research and Practice}

While education is often discussed in socio-economic terms, this article has highlighted the politics of education-in terms of both the political aspirations ascribed to formal schooling by young refugees themselves, and the way in which education intersects with other power relations in decision-making processes in families, households, communities, and policy spaces. The data presented in this article demonstrate that, while there is no automatic linkage between formal schooling and stable, well-paid employment, young people like Marie who complete secondary or tertiary education gain socio-political status in families and communities. Moreover, they are more likely to be visible and vocal in policy and programming decision making with government authorities, UN agencies, and non-governmental organizations.

It is important that practitioners and researchers working in migration contexts recognize this politicization of education, because it presents opportunities for social transformation, but it can also entrench power relations, especially through intersectionality with other factors, such as class, social age, and gender. On the one hand, provision of "free" or subsidized education in refugee contexts may allow access for those who would otherwise be unable to afford it. Indeed, according to the headmaster of Bujubuli Secondary School in Kyaka II, the fact that school fees are much lower than those in surrounding Ugandan and Congolese schools has been a pull factor to the settlement, including for some Congolese who were previously living in, or whose families have since returned to, the DRC. This is corroborated by data presented in this article, including the fact that young people without their parents were disproportionately represented in the secondary school. Increased access for those who would otherwise not be able to afford formal education could potentially change the socio-political landscape as "peasants" and "villagers" join "intellectuals" in schools.

On the other hand, even "free" or subsidized education is still beyond the economic means of many Congolese (and Ugandans). Those attending primary school still have to pay for books, supplies, and "community contributions" to school lunch and maintenance programs. School fees at the secondary school are still prohibitively high for many, at one point sparking a peaceful demonstration in Kyaka
II. ${ }^{22}$ Moreover, formal education entails a prohibitively high opportunity cost for many families that rely on children's and young people's productive and reproductive labour. Indeed, school authorities at the primary and secondary schools in Kyaka II report low attendance during periods of peak agricultural activity (planting and harvest) in the settlement. This means that young people from poorer socio-economic backgrounds are less likely to go to school and/or to continue to higher levels of education.

Refugee organizations must more proactively address this intersection of language, class, and education when interacting with refugees. Similarly, researchers must consciously seek out research subjects from different socio-economic backgrounds. One concrete way to increase the visibility of working class refugees in policy dialogue and data collection is to place greater emphasis on local language training for organizations' staff and researchers. This would allow greater direct access of refugees with little or no formal education to policy makers taking important decisions about their lives. Indeed, this article has revealed the ways in which access to formal education and decision-making processes at various levels are interrelated. Overlooking the politics of education can thus undermine its transformative potential and instead entrench unequal power relations within refugee contexts.

\section{Notes}

1. Christina Clark-Kazak, Recounting Migration: Political Narratives of Congolese Refugees in Uganda (Montreal: McGill-Queen's University Press, 2011).

2. Nicola Ansell, Children, Youth and Development (London and New York: Routledge, 2005); Patricia Jeffrey and Roger Jeffrey, "Silver Bullet or Passing Fancy? Girls' Schooling and Population Policy," in Feminist Visions of Development: Gender Analysis and Policy, ed. Cecile Jackson and Ruth Pearson (London: Routledge, 1998).

3. See, for example: Sarah Dryden-Peterson, "Educating Refugees in Countries of First Asylum: The Case of Uganda," Migration Information Source (2004); Sarah Dryden-Peterson, "Education of Refugees in Uganda: Relationships between Setting and Access," (Kampala: Refugee Law Project, 2003).

4. A new refugee bill passed in 2006 currently makes it legal for refugees to live in the city and to receive assistance.

5. Karen Jacobsen and Loren Landau, "Researching Refugees: Some Methodological and Ethical Considerations in Social Science and Forced Migration," UNHCR Working Paper no. 90 (Geneva: UNHCR, 2003).

6. Carole McCann and Seung-Kyung Kim, "Definitions and Movements: Introduction," in Feminist Theory Reader: Local and Global Perspectives, ed. Carole McCann and 
Seung-Kyung Kim (New York and London: Routledge, 2003).

7. Chantal Mouffe, The Return of the Political (London: Verso, 1993).

8. See, for example: Allison James, Chris Jenks, and Alan Prout, Theorizing Childhood (Cambridge: Polity Press, 1998); Philippe Ariès, Centuries of Childhood, trans. R. Baldick (Harmondsworth: Penguin, 1979); and Hugh Cunningham, Children and Childhood in Western Society since 1500 (London: Longman, 1995).

9. Christina Clark-Kazak, "Towards a Working Definition and Application of Social Age in International Development Studies," Journal of Development Studies 45 (2009).

10. This is a pseudonym. All names in this article have been changed in the interests of confidentiality.

11. For the full narrative and a more detailed explanation of methodology, see: Clark-Kazak, Recounting Migration: Political Narratives of Congolese Refugees in Uganda.

12. Equivalent to approximately US $\$ 2.50$ at the time of research.

13. Winsome Leslie, Zaire: Continuity and Political Change in an Oppressive State (Oxford: Westview Press, 1993).

14. See: Basile Mabusa, "The Crisis in Education: A Congolese View," in Footnotes to the Congo Story: An 'African Report' Anthology, ed. H. Kitchen. (New York: Walker and Company, 1967); and Wyatt MacGaffey, "Religion, Class and Social Pluralism in Zaire," Canadian Journal of African Studies 24 (1990).

15. The gender discrepancy is due to lower rates of enrolment and retention amongst females in higher levels of education in Kyaka II refugee settlement.

16. Ansell, Children, Youth and Development; Jo Boyden, Birgitta Ling, and William Myers, What Works for Working Children (Stockholm: Save the Children Sweden, 1998).

17. Christina Clark-Kazak, "The Politics of Protection: Aid, Human Rights Discourse and Power Relations in Kyaka II Settlement, Uganda," Disasters 34 (2009): 55-70.
18. See also: Marc Sommers, "Representing Refugees: The Role of Elites in Burundi Refugee Society," Disasters 19 (1995): 19-25.

19. For an explanation of social age, see the first section of this article and Christina Clark-Kazak, "Towards a Working Definition and Application of Social Age in International Development Studies," Journal of Development Studies 45 (2009).

20. See, for example: Kate Hampshire et al., "Liminal Spaces: Changing Inter-generational Relations among Long-Term Liberian Refugees in Ghana," Human Organization 67 (2008): 25-36; Keumjoo Kwak, "Adolescents and Their Parents: A Review of Intergenerational Family Relations for Immigrant and Non-immigrant Families," Human Development 46 (2003): 15-136; Edison Trickett and Curtis Jones, "Adolescent Culture Brokering and Family Functioning: A Study of Families from Vietnam," Cultural Diversity and Ethnic Minority Psychology 13(2007).

21. Christina Clark, "Livelihood Networks and Decision-Making among Congolese Young People in Formal and Informal Refugee Contexts in Uganda" (Brighton: Households in Conflict Network, Institute of Development Studies, University of Sussex, 2006).

22. This incident is analyzed in more detail in Christina ClarkKazak, "The Politics of Protection: Aid, Human Rights Discourse and Power Relations in Kyaka II Settlement, Uganda," Disasters 34, no. 3 (2009).

Christina Clark-Kazak is assistant professor in International Studies and resident faculty at the Centre for Refugee Studies, York University.

(C) Christina Clark-Kazak, 2010. This open-access work is licensed under a Creative Commons Attribution-NonCommercial 4.0 International License, which permits use, reproduction and distribution in any medium for non-commercial purposes, provided the original author(s) are credited and the original publication in Refuge: Canada's Journal on Refugees is cited. 